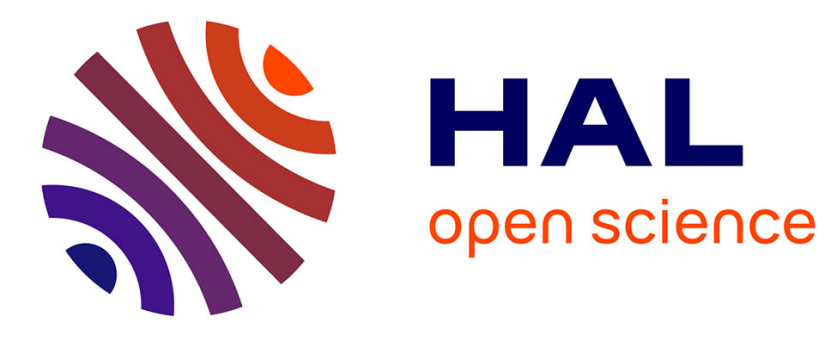

\title{
Original polystyrene nanoballs grown by plasma polymerization
}

\author{
Aboubakr Ennajdaoui, Mathieu Vogt, Mathieu Mougenot, Marjorie Cavarroc, \\ Pascal Brault, Jérôme Larrieu, Stéphanie Roualdes, Jean Durand
}

\section{- To cite this version:}

Aboubakr Ennajdaoui, Mathieu Vogt, Mathieu Mougenot, Marjorie Cavarroc, Pascal Brault, et al.. Original polystyrene nanoballs grown by plasma polymerization. IEEE Transactions on Plasma Science, 2011, 39, pp.2778-2779. 10.1109/TPS.2011.2105505 . hal-00688749

\section{HAL Id: hal-00688749 \\ https://hal.science/hal-00688749}

Submitted on 18 Apr 2012

HAL is a multi-disciplinary open access archive for the deposit and dissemination of scientific research documents, whether they are published or not. The documents may come from teaching and research institutions in France or abroad, or from public or private research centers.
L'archive ouverte pluridisciplinaire HAL, est destinée au dépôt et à la diffusion de documents scientifiques de niveau recherche, publiés ou non, émanant des établissements d'enseignement et de recherche français ou étrangers, des laboratoires publics ou privés. 


\title{
Original polystyrene nanoballs grown by plasma polymerization
}

\author{
Aboubakr Ennajdaoui, Matthieu Vogt, Mathieu Mougenot, Marjorie Cavarroc, Pascal Brault, Jérôme \\ Larrieu, Stéphanie Roualdès, and Jean Durand
}

\begin{abstract}
Plasma polymerization of styrene is widely used to synthesize polymer membranes for various applications. Under certain specific conditions, it is possible to grow polystyrene nanoballs. In this paper, we highlight the potential of plasma polymerization to synthesize polystyrene balls.
\end{abstract}

Index Terms - Plasma polymerization, styrene, nanoballs, low pressure.

$\mathbf{P}$ OLYSTYRENE nanoballs aroused interest in the past decade for their potential applications, in particular in the medical field. For example, Hayakawa's team used the polystyrene nanoballs to prevent the viruses' transmission in living cells [1]. In order to develop those polystyrene nanoballs, research has mainly been oriented towards chemical wet process, using conventional free radical or other traditional polymerization techniques [2]. However, plasma polymerization can also be used. Plasma polystyrene polymer formation occurs when styrene vapour is injected into glow discharge plasma, taking the form of a thin film deposited on all surfaces exposed to the plasma. Chemical reactions that occur under plasma conditions are, in nature, very complex.

Until now, Jiang's team was the only one to successfully produce nanoballs using PECVD techniques [3]. In its study, polymers nanoballs deposits, made of trifluoromethanesulfonic acid and 2- vinylpyridine mixture, are observed to grow as nanoclusters with an average diameters of $25 \mathrm{~nm}$. It assumed that the formation mechanism of these nanoballs might be similar to that of dust particles observed in several plasma processes such as thin film deposition, etching, or sputtering. In fact, so-called dusty plasmas generate a huge interest due to their

This work was supported by the Dreux Agglomeration Institution.

A. Ennajdaoui, M. Vogt, M. Mougenot and M. Cavarroc are with the Made In Dreux Innovation (MID), 4 rue Albert Caquot, 28500 Vernouillet, France. (e-mail: m.cavarroc@dreux-agglomeration.fr).

P. Brault is with the Groupe de Recherches sur l'Energétique des Milieux Ionisés (GREMI), CNRS-Université d'Orléans, 45067 Orléans Cedex 2 France.

J. Larrieu is with Tetra Pak SA, Development \& Engineering, Romont C.P. 32, 1680 Romont, Switzerland.

J. Durand and S. Roualdes are with the Institut Européen des Membranes (IEM), Université Montpellier II, Place Eugène Bataillon, 34095 Montpellier Cedex 5 France. ability to produce nanoparticles. However, even if dust formation is a well-known phenomenon, its effect on the plasma properties is not yet totally elucidated [4-5].

In our case, in this paper, we notice that in a certain range of plasma conditions associated to a specific reactor configuration, RF plasma discharge enabling to deposit plasma polystyrene nanoballs which have perfect spherical form and various sizes. Many applications are possible in particular in the medical and energy field.

The plasma polymerized styrene films were prepared in a commercial capacitively coupled plasma reactor (depicted in Fig. 1 (a)), pumped through a turbomolecular pump (ALCATEL ATH 400) for pre-deposition high vacuum and a primary pump (DVP Vacuum Technology - DC 16D) for the deposition process. The reactor is a cylindrical stainless steel chamber with the following dimensions: $600 \mathrm{~mm}$ long, $400 \mathrm{~mm}$ diameter. The pressure inside the chamber was sensed and monitored respectively by a MKS Baratron gauge (626A range $0-10 \mathrm{mbar}$ ) and a MKS throttle valve (type 253B). A liquid nitrogen trap was placed between the deposition chamber and the pumping system in order to protect the latter. A $13.56 \mathrm{MHz}$ radiofrequency (RF) source (Dressler CESAR 136) was used to supply power to a vertical plate electrode. This RF electrode is a removable disk electrode (15 cm diameter); in parallel the anode is a rotative (speed $\sim 6 \mathrm{rpm})$ squared electrode $(15 \times 15 \mathrm{~cm})$ at floating potential. The gap between both electrodes is $6 \mathrm{~cm}$. The glow discharge was activated by argon (Air liquid, purity $>99.999 \%$ ) dilution of the styrene gas. Argon was fed into the system via Horiba gas flow meter (SEC-E40). Styrene (Sigma Aldrich, purity > 99\%, liquid form) was introduced into the plasma reactor in vapor form with a home made bubbler device using argon as a carrier gas. In the container, the polymerization of styrene monomer was stabilized by adding $15 \mathrm{ppm}$ of 4-tertbutylcatechol. The precursor was introduced near the electrodes gap using a ring pipeline gas showering system to ensure a uniform distribution. The second ring is not used. All the gas lines were heated at $40^{\circ} \mathrm{C}$ to prevent the polymerization of styrene monomer. For all the plasma nanoballs depositions, the PECVD process pressure was kept constant at 0.25 mbar. The deposition duration is between 10 and $15 \mathrm{~min}$. The input power was fixed at $20 \mathrm{~W}$ and the argon gas flow meter was maintained constant at $10 \mathrm{sccm}$. SEM (S-4500 Hitachi $^{\circledR}$ ) was used for observation of polystyrene plasma films and nanoballs morphologies. We have selected some examples of the 


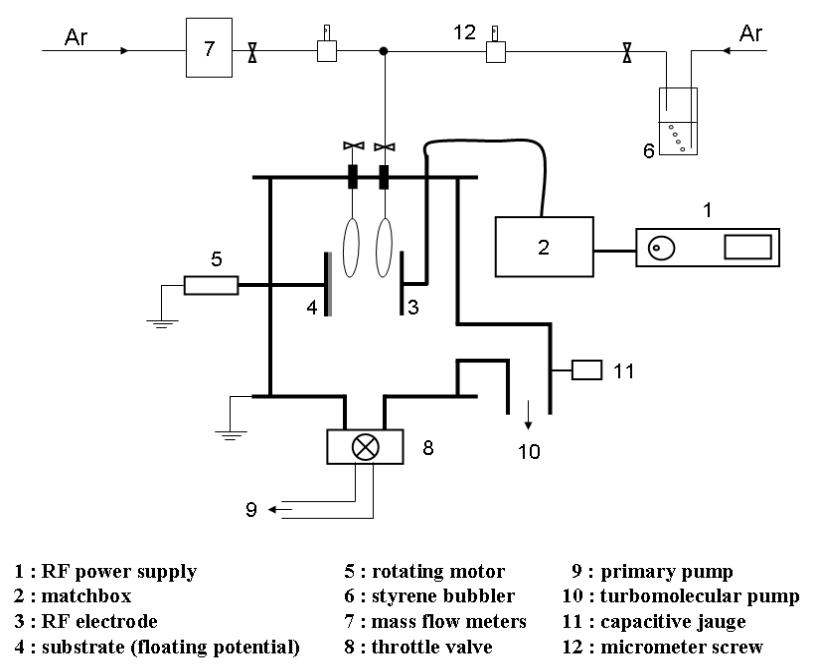

(a)

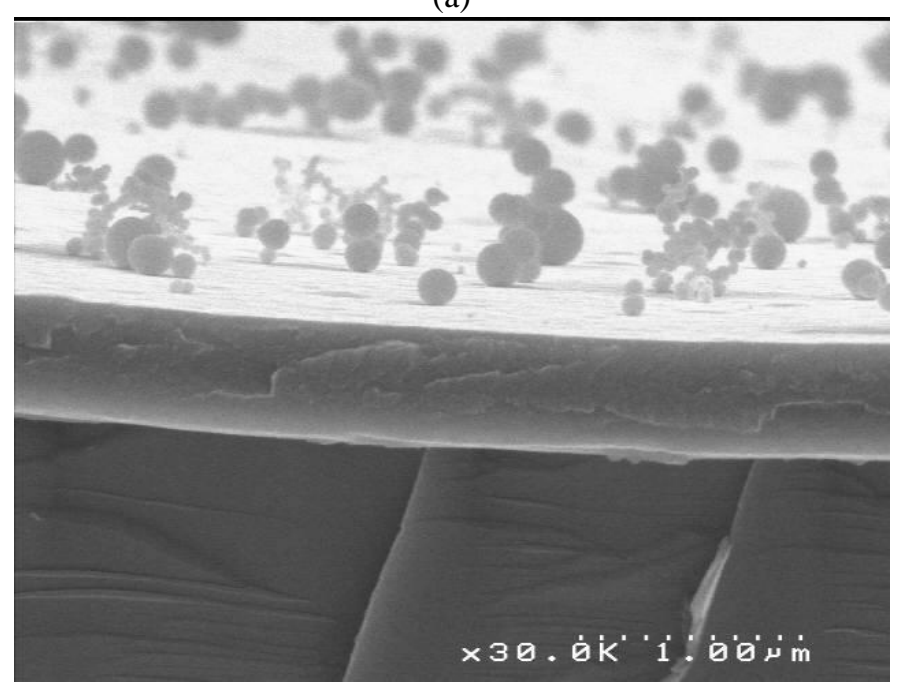

(c)

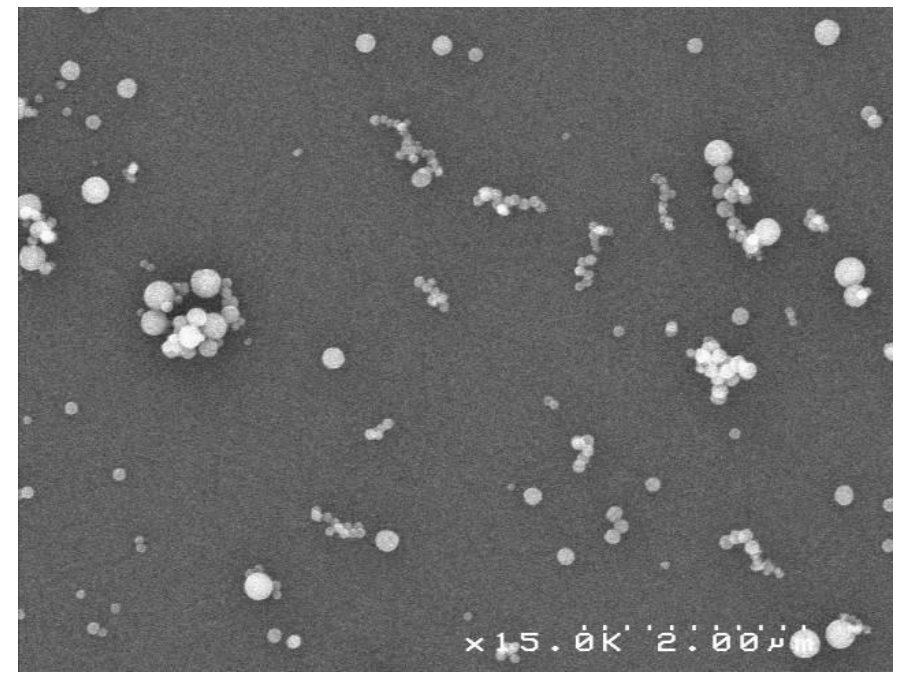

(b)

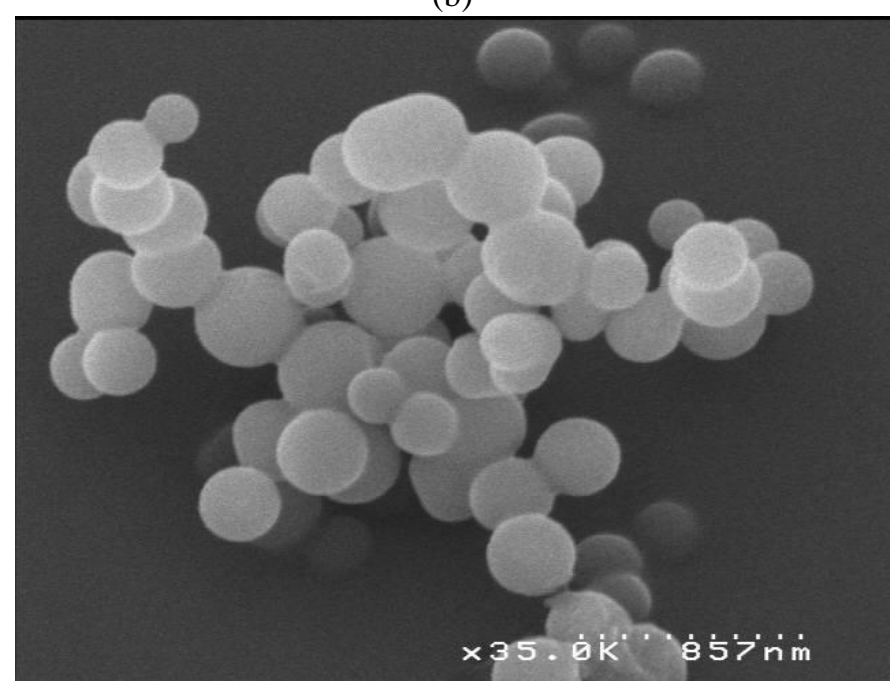

(d)

Fig. 1. (a) Polymerization device, (b) (c) Typical SEM surface and profile of a plasma polystyrene polymer on silicon support (S4500 Hitachi $^{\circledR}$ ), (d) magnification of polystyrene plasma nanoballs.

most expressive pictures. Fig.1 shows SEM profile and area of typical polystyrene plasma polymerized films deposited onto silicon support. In Fig. 1(b) polystyrene nanoballs exhibiting a diameter in the $20-250 \mathrm{~nm}$ range can be observed as in silicon based chemistry in [5]. Fig. 1(c) shows that the grown plasma polymer is quite dense. Fig. 1(d) shows that nanoballs tend to agglomerate together. A priori, by observation, the nanoballs construction begin in the gas phase. It is interesting to observe in the plasma polymer surface, that nanoballs growth contribute to the film formation in the same time. This phenomenon has already been observed in other carbon based dusty plasmas [4]. Among the variables influencing the development of nanoballs and plasma films surface, the pressure, the flow rate, and styrene injection device have been evidenced to be the most important. As a conclusion, we succeeded in synthesizing polystyrene nanoballs by plasma polymerization. Those nanoballs could be of interest in medical applications for instance.
New experiments are under progress in order to get a better comprehension of the involved dust formation mechanisms.

\section{REFERENCES}

[1] T. Hayakawa et al., "Concanavalin A-immobilized polystyrene nanospheres capture HIV-1 virions and gp120: Potential approach towards prevention of viral transmission," Journal of Medical Virology, vol. 56, no. 4, pp. 327-331, Dec. 1998.

[2] J. Lee, and Y. Liao, "Synthesis of polymeric nanofiber and polymeric nanosphere by living free radical polymerization," Journal of Applied Polymer Science, vol. 101, pp. 3550-3558, Sep. 2006.

[3] Z. Jiang, X. Yu, Y. Shi, Y. Meng, "The synthesis and characteristics of polymer nanoballs by plasma polymerization cooperating with DC plasma sputtering technique," Thin Solid Films, vol. 518, pp. 66096613, Sep. 2010.

[4] S. Hong, "From Thin Films to Nanoparticles: Investigation of Polymerization Processes in Capacitively Coupled Hydrocarbon Plasmas", Ph.D. dissertation, Dept. Phys. and Astronomy, Ruhr Univ., Bochum, 2004.

[5] M. Cavarroc et al., "Successive generation of dust in complex plasmas: A cyclic phenomenon in the void region" Phys. Rev. Lett., vol. 100, pp. 045001, Dec. 2007. 